\title{
Role of hymenopterous parasits Aphelinidae in the regulation of levels of Lepidosaphes beckii (Newton, 1869) (Homoptera Di- aspididae) populations on orange trees in Rouiba area (Algeria)
}

\author{
Lalia Boukhobza', Insaf Zaabta', Rachida Belguendouz², Fateh Mimeche ${ }^{3 *}$ \& Mohamed Biche' \\ ${ }^{1}$ National Superior School of Agronomy 16200 El Harrach Algiers, Algeria \\ ${ }^{2}$ Medicinal and Aromatic Plant laboratory. University of Blida \& Department of Biotechnology, Univ. Blida 1, (Al- \\ geria) \\ ${ }^{3}$ Department of Agricultural Sciences, University of M'Sila, BP 166 Echbilia, 28000 M'Sila, Algeria. \\ ${ }^{*}$ Corresponding author, email: mimechefateh@gmail.com
}

\begin{abstract}
This present study put in evidence the dynamics of the populations of Lepidosaphes beckii (Newton, 1869) (Homoptera Diaspididae), and the study of the impact of its hymenopterous parasites Aphytis lepidosaphes Compere, 1955, Aphytis chrysomphali Mercet, 1912, Aphytis proclia Walker, 1839 and Aspidiotiphagus citrinus (Craw, 1831) on orange tree in the area of Rouiba. This diaspine develops three generations: one in autumn-winter, one in spring and one in summer. This scale insect presents a very marked affinity in the middle of the tree and the inferior faces of the leaves where the suitable conditions for its development seems to be offered. The natural mortality of $L$. beckii is of two types: climatic for young stages and physiological for the adult females. The parasitic incidence is almost the same for the young stages and the adult with respectively $22.24 \%$ and $23.89 \%$. The global rate of parasitism is $23.24 \%$ insufficient to control its host.
\end{abstract}

KEY WORDS Aphytis; Aspidiotiphagus; Citrus; Lepidosaphes beckii; parasitoids.

Received 19.03.2020; accepted 28.09.2020; published online 22.11.2020

\section{INTRODUCTION}

The cultivation of citrus fruits is of strategic importance for Algeria where it is a source of fruit supply and opportunities in the international market for citrus products. Among the Citruses, the Orange tree occupies the first place with $69.73 \%$, then the Lemon tree with $6.94 \%$, the Mandarin with $4.73 \%$ and the clementine with $1.82 \%$. The citrus orchards are subjected to very high-pressure by several pests, in particular by the cochineals that appear to be the second pest after the Mediterranean fruit fly (Benassy \& Soria, 1964). The diaspines represent $42.37 \%$ of all the cochineals and the genus Lepidosaphes Shimer, 1868 (Homoptera Diaspididae) is the most dominant with $14 \%$ (Belguendouz, 2005). While the cochineals in general, and Lepidosaphes beckii (Newton, 1869) in particular, cause important damages on citrus fruits, there are, however, predators and pests very poorly known in Algerian conditions. Our work 
presents a contribution to the understanding of the ecology of $L$. beckii on Orange trees in the region of Mitidja, and its relationship with the parasites Hymenopter.

\section{MATERIAL AND METHODS}

Our study was carried out on a private farm in Rouiba (36 $44^{\circ} 00^{\prime \prime} \mathrm{N}$ and $3^{\circ} 17^{\prime} 00$ ' $\left.\mathrm{E}\right)$, located to the east of the Mitidja, $25 \mathrm{~km}$ from the capital Algiers and $7 \mathrm{~km}$ from the Mediterranean Sea. It is delimited to the north by the town of Ain-Taya, to the south by the town of Khemis El Khechna, to the east by the town of Reghaia and to the west by the town of Dar El Beida, over a period from September 2016 to July 2017. The plot is 2 hectares, divided into 9 blocks of 25 trees. Prospecting was done once per 10 days, with a sampling of 2 trees from each block on which we took 1 branch of $20 \mathrm{~cm}$ long and 2 leaves (in each cardinal direction as well as in the center of the tree). The collected plant material were brought back to the laboratory where we counted for each stage the total live, dead and parasitized individuals of Lepidosaphes beckii in order to assess the condition of the insect infestation and the evolution of its pests in according to the method of Vasseur \& Schvester (1957).

\section{Identification technique for identified pests}

The identification of Aphelinidae is based on the study of their morphological characters (Ferrière, 1965). The technique consists in organizing the parasites harvested under a binocular loupe between blades and lamellae. The latter fixed by Faure's liquid. In our study, 4 species of parasites were identified on the populations of L. beckii: Aphytis lepidosaphes, Aphytis chrysomphali, Aphytis proclia, which are ectoparasites, and Aspidiotiphagus citrinus, which is an endoparasite.

\section{RESULTS AND DISCUSSION}

\section{Biology of the insect scale}

The analysis of the results reported in figure $1 \mathrm{a}$ cross-breeding between larval and adult elements, which is dictated by the natural life cycle of L.beckii where the percentages of these two populations are almost equal until mid-December when the larvae are present with $31.63 \%$ of the total number of individuals. Then there is a further progression in mid-January that reaches $76.30 \%$. These are likely from the adult females during autumn. Thereafter, the larval populations will undergo gradual regression and reach their lowest rate by the end of April. A further increase in staffing is then noted for the highest rate in July $(81.59 \%)$. For adult fluctuations, the adults displayed their highest percentage $(68.37 \%)$ only at the beginning of December. These females are likely the cause of the larvae observed during the month of November. Thereafter, these adult forms display a second peak $(75.33 \%)$ in the first then days of May (Fig. 1).

The results indicate an overlap of three annual generations in L. beckii: spring, summer and autumn generation. Our results confirm those reported by Biche et al. (2011), Biche et al. (2012), Adda (2010) in the same region of the Orange tree. On the other hand, Meghazi (2010) found 2 generations: fall and spring on the Orange tree in Rouiba. Benassy et al. (1975) reported that the Cochineal develops 2 generations per year in France, 3 in Tunisia, 4 in Naples (Italy), Egypt and Morocco. In Chile, Zuniga (1971) reported three annual generations in the northern region, two to three generations in the central region and only one generation in the southern region. On the other hand, in Eastern Cape in South Africa, De Villiers (1998) reported four annual generations.

The overall study of L.beckii shows that the central orientation is affected the most by this

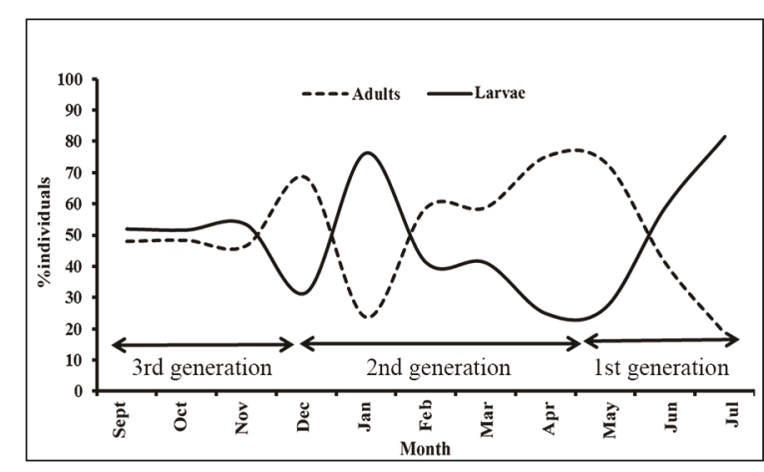

Figure 1. Fluctuation of larval and adult populations of Lepidosaphes beckii. 
cochineal with $38.36 \%$, followed by the eastern orientation with $22.12 \%$ of the total population (Fig. 2). Our results coincide with those obtained by Gherbi (2010) and Meghazi (2010) who worked in the same region. On the other hand, on the clementine trees, Mouas (1987), who worked in Annaba, and Khoudour (1988) in the Chebli region, report that $L$. beckii is found in the northern orientation. The vegetal organ has a very remarkable influence on the abundance of this cochineal, where the leaves contain $91.90 \%$ of the total population, mostly on the lower surface (56.31\%)than on the upper surface $(35.59 \%)$ (Fig. $2)$. This situation provides the cochineal with favorable fixation conditions. Indeed, the leaf blade has a very fine texture, favouring the bites of opophages insects. Our results are consistent with those found by Gherbi (2010). On the other hand, Mouas (1987), Khoudour (1988), Adda (2006) and Adda (2010) note that the highest rate of the living population of $L$. beckii is located in the upper surface of the leaves.

\section{Study of mortality}

In view of the results shown in the figure below, we note that overall mortality is significantly higher in larval populations $(43.87 \%)$ than in adult populations $(30.86 \%)$. Nevertheless, considerable fluctuations have been recorded throughout the period of study, stretching from September to July (Fig. 3). This mortality is likely related to the structure of the larval shield and the climatic conditions of the winter season where the minimum temperatures displayed $6.2^{\circ} \mathrm{C}$ in December, $2.3^{\circ} \mathrm{C}$ in February and $7.6^{\circ} \mathrm{C}$ in March. Instead, the strong rainfall recorded during the month of May was 75 $\mathrm{mm}$, compared to $18 \mathrm{~mm}$ in April and $2.55 \mathrm{~mm}$ in June. Regarding adult mortality, it is mostly physiological. Indeed, the females after oviposition, die immediately. Mouas (1987), Meghazi (2010), and Gharbi (2010) found that overall adult mortality is quite significant in larvae.

The recorded results show that the overall mortality rate remains very high where the abundance of the cochineal is very pronounced. Nevertheless, the highest mortality rates were recorded at the central and southern orientation of the tree, with $19.78 \%$ and $16.84 \%$, respectively, while on leaves is $52.72 \%(52.72 \%)$ (Fig. 4). This

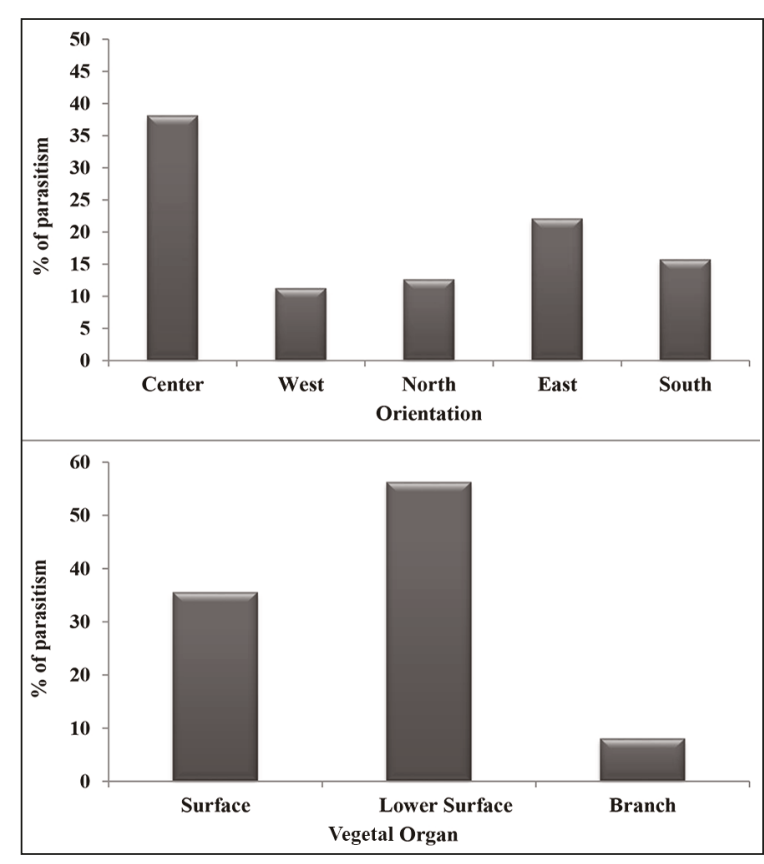

Figure 2. Spatiotemporal distribution of the overall population of Lepidosaphes beckii

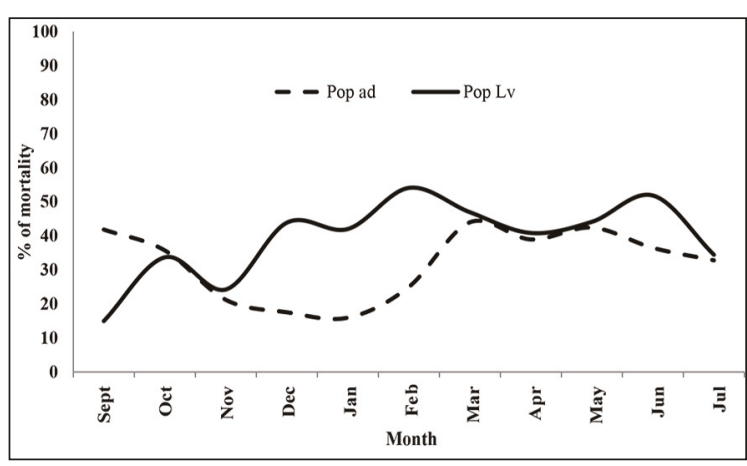

Figure 3. Mortality of Lepidosaphes beckii larvae and adults on the orange tree.

result is probably related to the exposure of these leaves to the different climatic hazards during the winter or summer period, namely high temperatures, winds, and hail, as well as the chemical treatments carried out in the orchard.

\section{Inventory of cochineal pests listed on Orange tree at Rouiba}

Periodic and random sampling of parasite populations remains an efficient method that allows, in addition to the inventory, to clarify 
certain bioecological parameters, on the one hand, and, on the other hand, to assess possibly the entomological role of each species identified for their biological control jobs. The parasite inventory of $L$. beckii highlights 4 species of Hymenoptera Aphelinidae represented by Aphytis lepidosaphes Compere, 1955, Aphytis chrysomphali Mercet, 1912, Aphytis proclia Walker, 1839 and Aspidiotiphagus citrinus (Craw, 1831) (Table 1).

Aphytis lepidosaphes is an ectoparasite that develops at the expense of females adult and 2 nd stage male larvae.

Aphytis chrysomphali, Aphytis proclia are ectoparasites that develop at the expense of 2 nd stage male larvae.

Aspidiotiphagus citrinus is an endoparasite that develops at the expense of the larvae of 2nd stage larvae of $P$. ziziphi and of young females (Ferrière, 1965). We found it for the first time on female larvae in Algeria.

\section{Study of the Parasite incidence}

The results recorded in the graph below show that the overall rate of all-stage parasitism in L.beckii fluctuates throughout the study period. This fluctuation first passes through a first peak during November with a rate of $30.49 \%$ and the second peak in April with a rate of $20.64 \%$ and reached the highest rate of parasitism during the month of July with $67.62 \%$ (Fig. 5). Overall, the parasitism recorded in the populations of L.beckii is $23.24 \%$. This rate is similar to that reported by Meghazi (2010) who worked in the same region of the Orange tree $(20.45 \%)$. On the other hand, compared to the work of Adda (2006), the parasitic incidence was higher, as the author noted $4.01 \%$ adult parasitism. This is likely due to the declining chemical treatments carried out in the study orchard.

The fluctuation of parasitism goes through two main periods: autumn-winter and spring-summer. During the first period, rates varied between $53.81 \%$ (September) and $25.58 \%$ (December), due to the availability of host larvae for parasites during this period. Thereafter, Parasitism parasitism considerably decreases to vary between $13.78 \%$ (January) and 11.03\% (February). This decrease is likely related to pesticide application in the study orchard. There was not parasitic activity in the

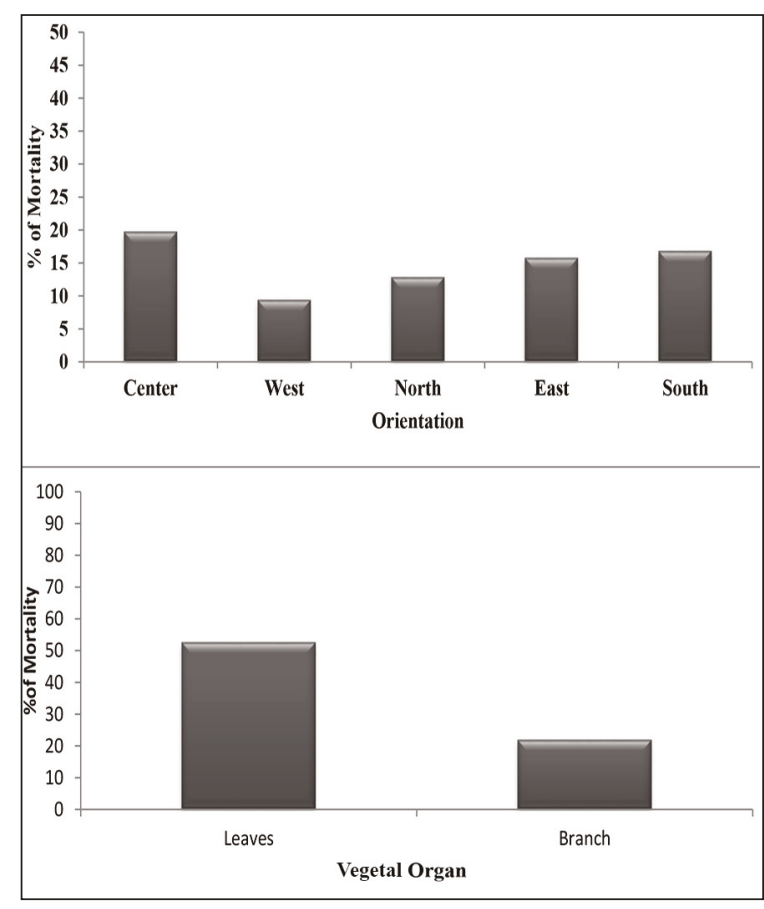

Figure 4. Spatiotomporel mortality of de Lepidosaphes beckii.

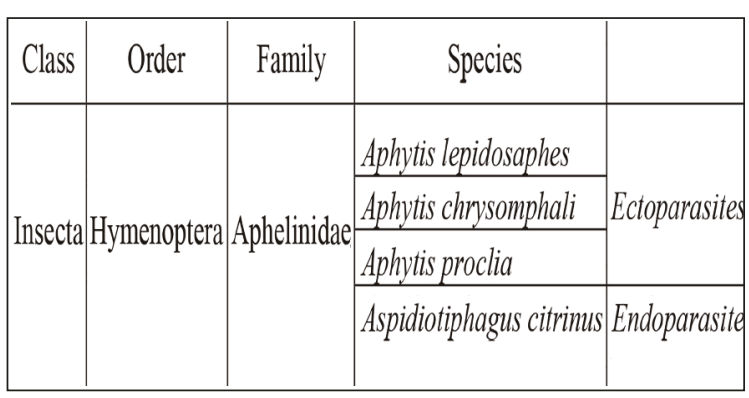

Table 1. Description of the parasites of Lepidosaphes beckii on the orange tree in the region of Rouiba.

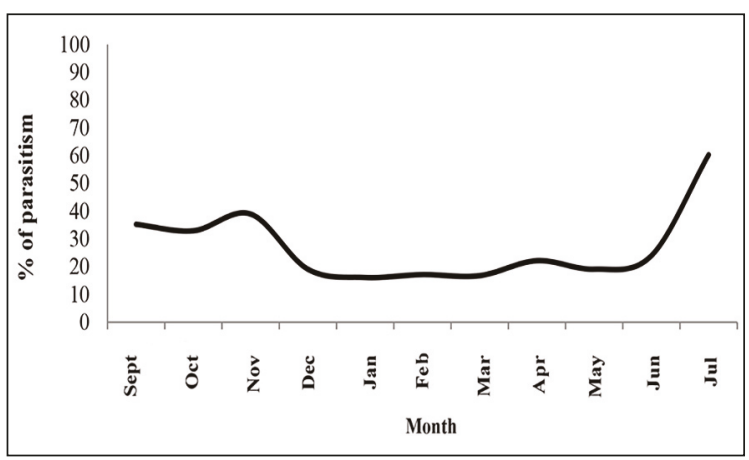

Figure 5. Overall Parasite Incidence of Lepidosaphes beckii populations 
larval populations until the end of March. In fact, the parasitism of this second period varies between 24.94\% (April) and 28.65\% (July) (Fig. 6).

Due to the availability of agreater presence of adult cochineal stages, and in contrast to larval populations, the parasite incidence in adults noted for 3 periods: autumn-winter, spring and summer. The first peak of the parasite incidence was recorded in November with $30.49 \%$, the second in April with $21.72 \%$ and the third in July with $67.62 \%$ (Fig. 7).

Based on the results obtained, it appears that the orientation and the vegetal organ do not have a significant effect on the distribution of the parasite on the tree. Abundance of host cochineals would result in a synchronous increase in the numbers of the parasite populations (Fabres, 1979). Nevertheless, the highest parasitism were recorded in the, east and South, orientations, with $28.86 \%$ and $28.75 \%$, respectively (Fig. 8 ). It should be noted that the lowest rate recorded was in the population in the central orientation of the trees. Pests seem to avoid shady areas of the tree and prefer to look for cochineal fixed in sunny places. Our results are similar to those reported by Adda (2006) and Meghazi (2010), whose northern orientation is the most preferred by parasitism.

For the spatial distribution of pests, it should be noted that the latter are more active on the upper surface $(27.16 \%)$ than on the lower surface of the leaves $(21.47 \%)$ and twigs (18.24\%). These places seem to explain the requirement of parasites in micro-climatic conditions since in these places the sunshine is better.

The host's females perforated shields correspond to the release of adult parasites and reveal the

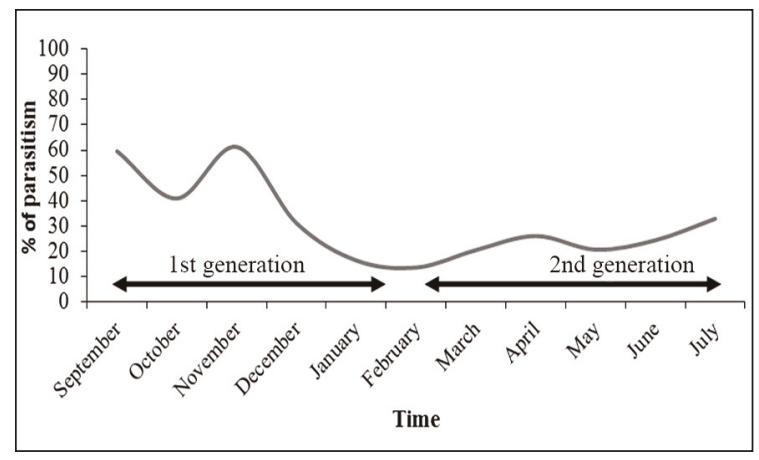

Figure 6. Parasite impact of larval populations of Lepidosaphes beckii presence of parasitoids. During the study period, we found the presence of a very large number of these females shields and puparia holes. However, they display three peaks, including 217 females shields and puparia holes in the month of October, then 509 in March and lastly in June with 436 females shields and puparia holes (Table 2).

\section{Comparative global parasitism rate}

Based on the results recorded in figure 9, it is apparent that the parasitoids attack much more the female stages of the cochineal, in wich $23.89 \%$ of the adults are parasitized. On the contrary, the males are attacked throughout their life cycle, which provides the parasitoid with nutritional conditions for better development. We also noted that parasitism remains constant in the female population throughout the study period with fluctuations in three peaks; the first in November (30.70\%), the second in April (21.7\%) and the third in July (67.90\%) (Fig. 9). A similar work in Egypt, on the incidence of external parasites of L. beckii, has shown that rates of parasitism are not very high. In fact, Hafez et al. (1987) reported rates of parasitism between 29.7 and $40.2 \%$ in OctoberDecember, $21.6 \%$ in January, 16,1\% in May and $15.4 \%$ in June.

The rate of parasitism of the males remains low compared to that of females with $19.11 \%$. Probably, the male stages do not offer the optimal nutritional conditions for better development of the parasitoid because they no longer feed during the nymph stages to become adult (Fig. 10).

The rate of parasitism in 2nd stage male larvae remained low at $7.42 \%$ compared with lin 2 nd stage

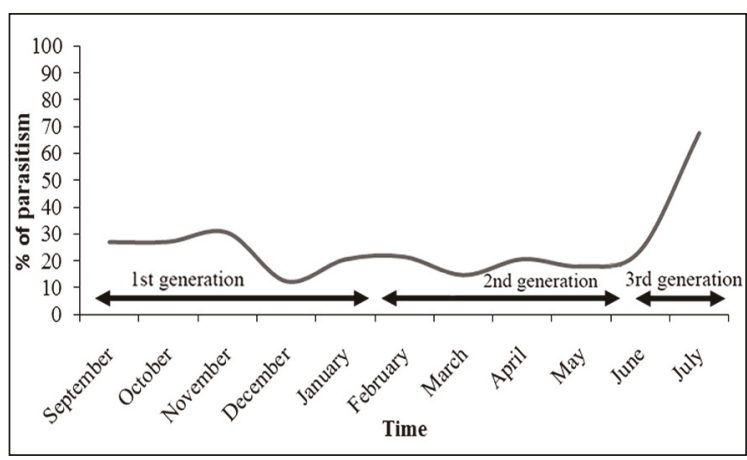

Figure 7. Parasite incidence of adult populations of Lepidosaphes beckii 
female larvae. Presumably, these male larvae do not offer optimal nutritional conditions for better development of parasitoid. Three peaks of parasitism have been observed: the first in October (43.18\%), the second in March (18.42) and the last in June (8.33\%) (Fig. 11).

Based on the results recorded in figure 12, it is apparent that parasitoids attack much more the female larval stages of the cochineal $(24.82 \%)$.

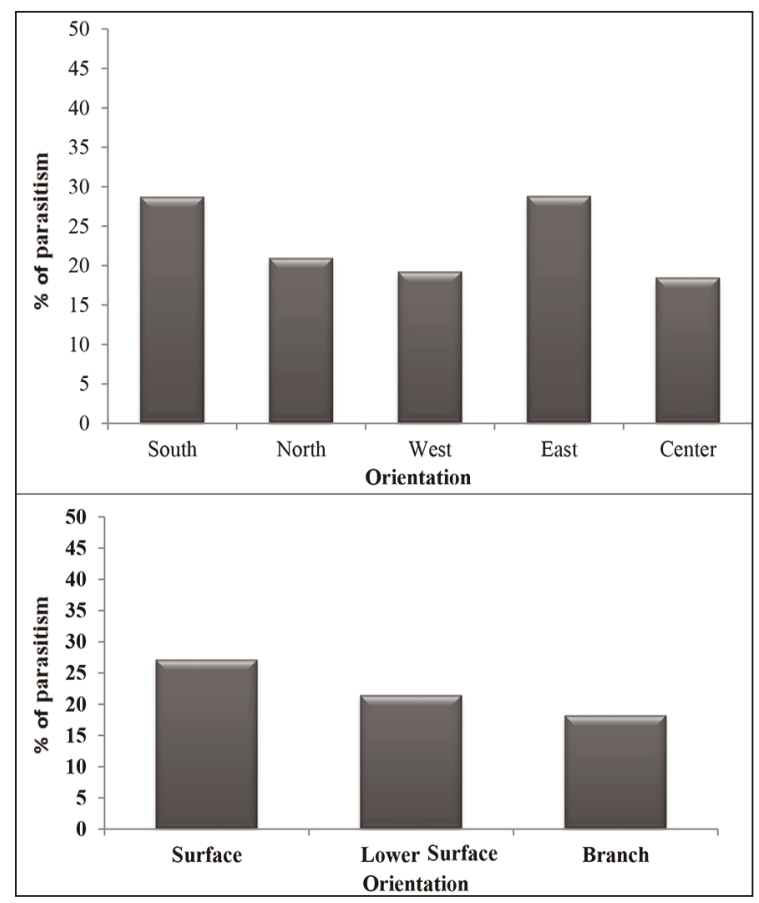

Figure 8. Parasite incidence of Lepidosaphes beckii populations according to the orientations and vegetal organs.

\begin{tabular}{|cccc|}
\hline Date & Shields holes & Puparias holes & (S+P) Holes \\
\hline September & 70 & 2 & 72 \\
October & 196 & 21 & $\mathbf{2 1 7}$ \\
November & 134 & 11 & 145 \\
December & 103 & 12 & 115 \\
January & 112 & 15 & 127 \\
February & 163 & 8 & 171 \\
March & 495 & 6 & $\mathbf{5 0 1}$ \\
April & 333 & 3 & 336 \\
May & 242 & 6 & 248 \\
June & 435 & 1 & $\mathbf{4 3 6}$ \\
July & 290 & 10 & 300 \\
\hline Total & 2573 & 95 & $\mathbf{2 6 6 8}$ \\
\hline
\end{tabular}

Table 2. Parasitic incidence of parasites in Lepidosaphes beckii populations by taking into account holes puparias and females shields.
Given the availability of these larvae throughout our sampling, parasitoids provide the nutritional conditions for better development. We also noted that parasitism in these larvae goes through three peaks: the first during the month of September $(59.60 \%)$, the second during the month of November $(61.32 \%)$ were the highest rate and the third were recorded during the month of July (32.82\%) (Fig. 12).

\section{CONCLUSIONS}

The study allowed us to undertake a new relative approach to the role of parasites Hymenoptera Aphelinidae in limiting populations of $L$. beckii. However, the study of the population dynamics of the pest is a key element in understanding the biological phenomena that govern the evolution of the pest during the seasons and to better define the techniques of control to adopt.

Based on the results obtained, we conclude that there is an overlap of three generations in year of L. beckii: one in autumn-winter, one in spring, and one in summer. The spatial distribution of this species on the tree is closely related to the microclimate created within the tree from which the species has a marked preference for its central orientation. This place seems to give it the favorable conditions for its optimum development.

The incidence of natural enemies is the result of the action of Hymenoptera parasites of the genus Aphytis Howard, 1900 and Encarsia Foerster, 1878, whose activity is mainly noticeable in full and spring. Three ectoparasites Hymenoptera species have been identified in the populations of $L$. beckii, A. lepidosaphes, $A$. chrysomphali, and A proclia, and a single endoparasite species, Aspidiotiphagus citrinus, during our study. It should be noted that this is the first time in Algeria that the presence of these parasitoids on the larval forms of the cochineal is observed. All of the studies conducted so far on the Diaspines have never reported this type of information.

We noted that $A$. lepidosaphes is present only in adult males and females. However, they are much more present on the females of the cochineal as it offers optimal nutritional conditions. The overall rate of parasitism approximates $23.89 \%$. Two 


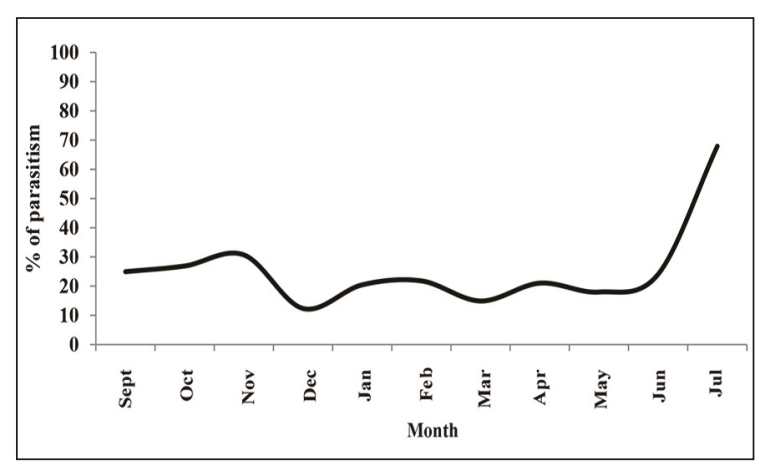

Figure 9. Parasite incidence of $A$. lepidosaphes on females Lepidosaphes beckii.

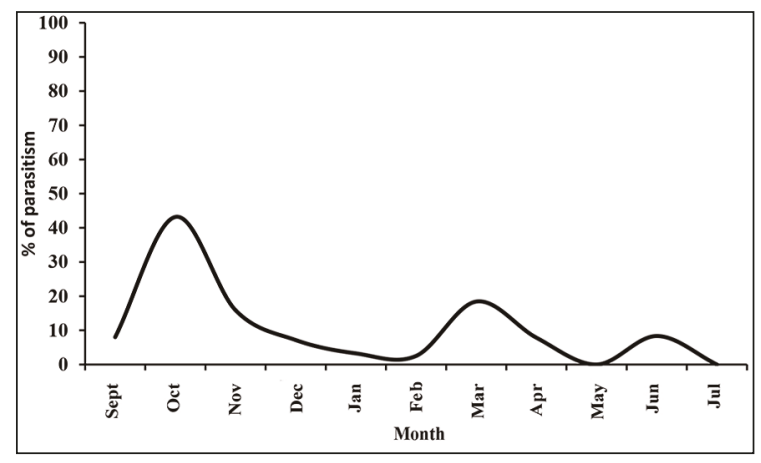

Figure 11. Parasite incidence of A. chrysomphali and A. proclia on 2nd stage male larvae of Lepidosaphes beckii.

ectoparasites, $A$. proclia and $A$. chrysomphali, with a parasitism rate of $7.01 \%$, and an endoparasite $A$. citrinus, were identified on $2^{\text {nd }}$ stage male larvae. The latter is the only parasite that develops on $2 \mathrm{nd}$ stage female larvae with an overall rate of $22.19 \%$.

Our work provides further information on the impact of parasitoids A. lepidosaphes, $A$. chrysomphali, A. proclia and Aspidiotiphagus citrinus, for a possible rational management of integrated control methods in good conditions.

\section{REFERENCES}

Adda R., 2006. Rôle d'Aphytis Lepidosaphes (Hymenoptera; Aphelinidae) dans une population de cochenilles diaspines (Homoptera; Diaspididae) dans un verger de citronnier à Rouiba. Mémoire d'ingénieur, Ecole National Supérieure Agronomique. El-Harrach. Alger, 125 pp.

Adda R., 2010. Effet du Spirotrtramate (insecticide) sur un peuplement de cochenilles diaspines dans un

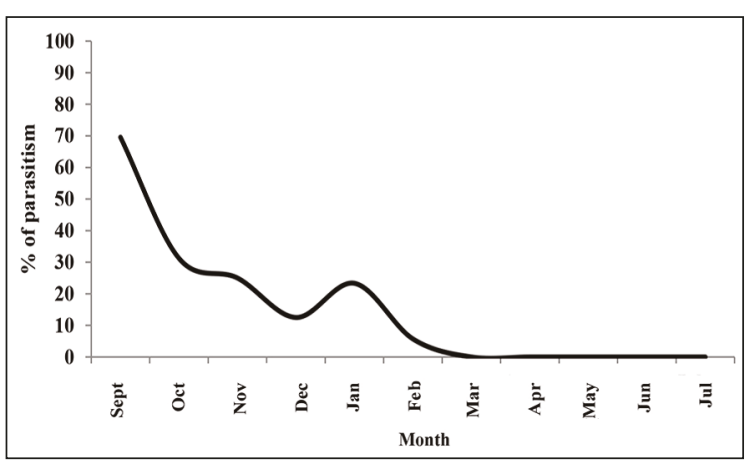

Figure 10. Parasite incidence of $A$. lepidosaphes on the males of Lepidosaphes beckii.

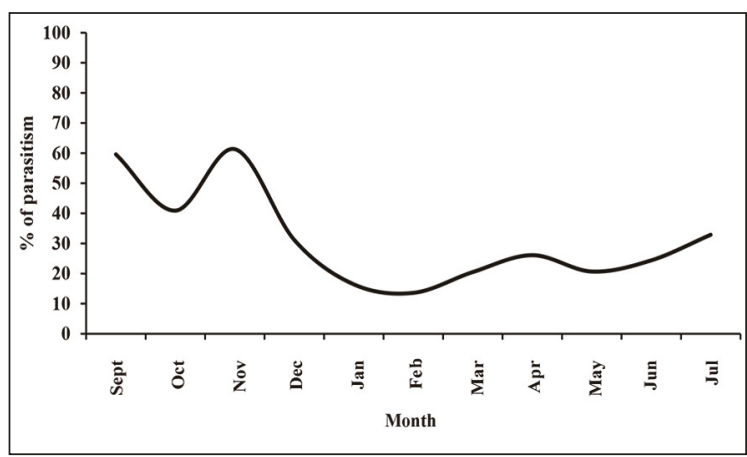

Figure 12. Parasite incidence of $A$. citrinus on 2nd stage female larvae of Lepidosaphes beckii

verger d'agrumes à Rouiba. Mémoire. Magistère., Ecole National Supérieure Agronomique. ElHarrach, Alger, 125 pp.

Belguendouz R., 2005. Biosystématique des cochenilles diaspines d'Algérie. Mémoire. Magistère, Ecole National Supérieure Agronomique. El-Harrach, Alger, $86 \mathrm{pp}$.

Benassy C. \& Soria F, 1964. Observations écologiques sur les cochenilles diaspines nuisibles aux agrumes en Tunisie. Annales Instrument Type Rating Examination, I.N.R.A.T., 37: 193-222.

Bénassy C., Bianchi H. \& Franco E., 1975. Utilisation en France d'Aphytis lepidosaphes Comp. (Chalcidien, Aphelinidae) parasite spécifique de la cochenille virgule des Citrus (Lepidosaphes beckii Newm.). II. Données préalable sur l'évolution du parasite. Revue Fruits, 30: 267-270.

Biche M., Siafa A., Adda R., Agagna Y. \& Sellami M., 2011. Evaluation du Spirotetramate sur les populations de Lepidosaphes beckii sur des agrumes en Algérie. Bull. OILB - IOBC/wprs, Integrated Control in Citrus Fruit Crops, 62: 123-131

Biche M., Siafa A., Adda R. \& Gharbi R., 2012. Biologie 
de Aonidiella aurantii (Homoptera, Diaspididae) sur citronnier dans la région de rouiba (Algérie). Lebanese Science Journal, 13: 59-64.

De Villiers J.F., 1998. Citrus mussel scale: Lepidosaphes beckii (Newman) [=Cornuaspis beckii (Newman)]. 149-153. In: Bedford, E.C.G., Van den Berg, M.A. \& De Villiers, E.A. (Eds.), Citrus pests in the Republic of South Africa. Institute for Tropical and Subtropical Crops, Nelsprui, $288 \mathrm{pp}$

Ferrière C.H., 1965. Hymenoptera - Aphelinidae d'Europe et du bassin méditerranéen. Ed. Masson et Cie., Paris, 203 pp.

Gherbi R., 2010. Impact du complexe coccinelles coccidiphages parasites hyménoptères dans des peuplements de cochenilles diaspines (Homoptera ; Diaspididae) sur agrumes à Rouiba. Mémoire. Magistère., Ecole National Supérieure Agronomique. El-Harrach. Alger, 87 pp.

Hafez M.B., El-Minshawy A.M. \& Donia A.R., 1987. Parasitic efficiency oof some hymenopterous Aphytis spp on the purple scale insect Lepidosaphes beckii New Journal of Applied Entomology, 103: 135-138. https://doi.org/10.1111/j.1439-0418.1987.tb00970.x

Khoudour A., 1988. Dynamique des populations de Lepidosaphes beckii (Homoptera, Diaspididae) dans un verger de clémentinier à Chebli. Mémoire d'ingénieur, Ecole National Supérieure Agronomique. El-Harrach, Alger, 60 pp.

Meghazi N., 2010. Rôle du parasitoïde Aphytis lepidosaphes (Hymenoptera: Aphelinidae) dans la limitation des populations de Lepidosaphes beckii (Homoptera : Diaspididae) sur oranger dans la région de Rouiba. Mémoire d'ingénieur, Ecole National Supérieure Agronomique. El-Harrach, Alger, 112 pp. Mouas B., 1987. Bioécolgique de la cochenille virgule Lepidosaphes beckii Newman (coccidae, Diaspididae) dans un verger de clémentinier Citrus reticulata dans le domaine Chaoui Mabrourk (Annaba). Mémoire d'ingénieur, Ecole National Supérieure Agronomique. El-Harrach. Alger, 76 pp. Vasseur R., \& Schvester D., 1957. Biologie et écologie du pou de San José (Quadraspidiatus perniciosus Comst) en France. Annales Instrument Type Rating Examination, I.N.R.A.T., 8: 5-161.

Zuniga S.E., 1971. Biología de la conchuela morada, Lepidosaphes beckii (Newm.) en trea areas citricolas de Chile (Homoptera : Diaspididae). Revista Peruana de Entomología, 14: 285-290. In: Annales du $1^{\mathrm{er}}$ Congrès Latino-américain d'Entomologia, CuscoPerù 12-18 Abril 1971. 